\title{
Investigating Teachers' Perceptions of Facilitating Scientific Investigations
}

\author{
Israel Kibirige ${ }^{1^{*}}$ (D), William Lesiba Teffo ${ }^{1}$ (D), Suresh Singh ${ }^{1}$ (D) \\ ${ }^{1}$ Department of Mathematics, Science \& Technology Education (DMSTE), University of Limpopo, SOUTH AFRICA
}

Received 1 July 2021 - Accepted 16 December 2021

\begin{abstract}
The study explored science teachers' perceptions of Scientific Investigations (SI) and their classroom practices in South Africa. An explanatory sequential design using qualitative and quantitative approaches was used. Qualitative data were collected first using interviews and classroom observations, followed by quantitative data using a questionnaire. Qualitative data were thematically analysed, whereas quantitative data were analysed using descriptive statistics: percentages; and inferential statistics: $t$-test; Analysis of Variance (ANOVA); and Honest Significant Differences (HSD) Tukey. Three themes emerged from qualitative data: different perceptions of SI, challenges in teachers' skills, and resource challenges in schools. Quantitative results show teachers from differently resourced schools had diverse perceptions of practical work, inquiry, and SI (ANOVA, $p=.04$ ). These perceptions included confining hands-on activities to practical work, and limiting inquiry to oral questioning. Teachers' challenges in facilitating $\mathrm{SI}$ included inadequate skills and a lack of resources. These findings have far-reaching implications for learners' science achievements and policymakers.
\end{abstract}

Keywords: teachers' perceptions, scientific investigations, inquiry, practical work, classroom practices

\section{INTRODUCTION}

Globally, science teaching has focused on investigations (Capps et al., 2016). Scientific Investigations (SI) aim to improve science teaching and learning (Beck et al., 2010). According to Next Generation Science Standards (NGSS), there are eight scientific practices based on the InteractiveConstructive-Active-Passive framework (ICAP) (Chi \& Wylie, 2014). This framework underscores three areas: investigating, sense-making, evaluating and communicating (Chen \& Terada, 2021). In a different setting, The Framework for K-12 Science Standards (National Research Council [NRC], 2012) lists eight scientific practices, namely: 1) asking questions, 2) developing and using models, 3) planning and carrying out investigations, 4) analysing and interpreting data, 5) using mathematics and computational thinking, 6) constructing explanations, 7) engaging arguments from evidence, and 8) evaluating and communicating information for learning. These eight practices, according to Chi et al. (2018), improve learners' constructive learning. Research shows that teaching using laboratory work encourages learners to engage in experiments (Beck et al., 2010).

In Nigeria (Alebiosu, 2005) and Ghana (CharteyAmpiah et al., 2004), informal science experiences were integrated into formal science learning in inquirycentred classrooms to improve learners' understanding of science. South Africa's Curriculum Assessment Policy Statements (CAPS) in Specific Aim 2 states, "Investigating phenomena in Life Sciences." Thus, learners are expected to: "...confidently explore and investigate phenomena relevant to Life Sciences by using inquiry, problem-solving, critical thinking and other skills" (Department of Education, 2008, p. 23). Thus, Life Sciences teachers are expected to assess investigative skills once per term, accounting for $15 \%$ of the promotion marks in Grades 10 and 11 (Department of Education, 2011). While SI introduction in South Africa was timely, it caused tensions between the curriculum designers and teachers who implemented it (Tsakeni, 2018). The tensions have been attributed to teachers' low competencies and a lack of resources in many schools (Ramnarain, 2011; Tsakeni, 2018). The Department of Basic Education had not equipped all

(c) 2022 by the authors; licensee Modestum. This article is an open access article distributed under the terms and conditions of the Creative Commons Attribution License (http://creativecommons.org/licenses/by/4.0/).

$\square$ israel.kibirige@ul.ac.za (“Correspondence) $\square$ Lesibadr@gmail.com $\square$ suresh.singh@ul.ac.za 


\section{Contribution to the literature}

- The study showed unique nuances in teachers' conceptualization of SI and their classroom practices when facilitating Scientific Investigations.

- The study highlights the challenges teachers face in facilitating Scientific Investigations.

- The study's findings have implications for the Department of Education to equip schools with the necessary SI materials and build the teachers' capacities to facilitate authentic Scientific Investigations.

schools with adequate science resources (Kazeni \& Onwu, 2013; Singh \& Singh, 2012). In addition, the Umalusi (2009) report showed poor quality science investigative activities in Continuous Assessment (CASS). Onwu and Stoffel (2005) suggest that South African teachers lack the knowledge and skills to facilitate SI. Therefore, this study explored teachers' perceptions of SI and their classroom practices in facilitating SI. Three questions and one hypothesis guided the study: 1) What are the science teachers' perceptions regarding practical work, inquiry, and Scientific Investigations? 2) How do teachers facilitate SI in the Life Sciences classrooms? 3) What challenges do teachers face in facilitating Scientific Investigations? Hypothesis, 'Teachers from differently resourced schools do not have different perceptions of practical work, inquiry, and SI.'

\section{Theoretical Framework}

The study employed the Social Constructivism theory (Vygotsky, 1978) to promote learner-centred activities, where learners work with their peers and teachers to tackle challenging activities. These activities improve learners' cognitive and psychomotor domains. In these settings, learners construct intrapersonal knowledge structures and meanings (Huang et al., 2010). The method motivates learners to complete challenging activities and become zealous to tackle complex activities (Vygotsky, 1978). Constructivism advocates for meaning-making through posing questions, solving problems, and constructing theories (Crotty, 1998). Knowledge is temporary, internally constructed, developmental, and socially mediated (Fosnot, 1996). Learners are expected to construct their meanings and understandings. Constructivism involves interaction between the existing knowledge and the new knowledge or experiences (Schunk, 2004). This theoretical framework guided researchers when probing teachers' experiences regarding facilitating $\mathrm{SI}$.

\section{LITERATURE REVIEW}

Scientific Investigations (SI) is a difficult term to define. Pyatt and Sims (2012) contend the term includes hands-on and minds-on activities. SI arouses learners' interest because they get scientific information through experimentation. During SI, learners are involved in the inquiry and practical work (Ramnarain \& Kibirige,
2010). The literature is presented in five parts: 1) Teaching and learning through learner activities (Teachers' classroom practices), 2) Facilitation, 3) Practical work, 4) Inquiry (Learners' role in the classroom), and 5) Scientific Investigations (Learners' and teachers' activities in the classroom).

\section{Teaching/ Learning Through Learner Activities}

Science teaching aims to develop learners' autonomy and competencies (Ramnarain, 2020). Learners' autonomy and active science learning align with the Zone of Proximal Distance (ZPD) of Vygotsky (1978). Teachers scaffold learners during SI (Leon et al., 2017), and learners collaboratively study science (Pang et al., 2018). In the 4th Industrial Revolution (4IR), learners can use digital devices to do various activities using Computer Simulations (CS) (Kibirige \& Tsamago, 2019) and interact online with their peers (Govender \& Skea, 2015; Kayembe \& Nel, 2019).

\section{Facilitation}

Teachers globally have challenges using authentic tasks in schools (Tilling, 2018). A study by SierraLlorente et al. (2018) noted that schools are more concerned with teachers' content and put little effort into understanding how they teach it. Similarly, Osborne (2015) found that some teachers did not facilitate handson activities. To facilitate learners includes (1) a teacher identifying learners' misconceptions (Alpaydin, 2017) and learning difficulties (Ngonyani, 2010), (2) collaborative work, and (3) reflection. Facilitating SI includes three stages: (1) Starting an activity, (2) proceeding with the activity, and (3) concluding an activity (Abdoola et al., 2017; Vrieling et al., 2018). Starting an activity is the initial stage in which the teacher invites and stimulates learners to take the first steps of doing an activity (Adofo, 2017). Proceeding with an activity is a stage in which learners generate workable solutions to the problem (Maulidya et al., 2017). The teacher intervenes to support learners (Vrieling et al., 2018) by checking the integration of SI skills and other skills, like numeracy, observing peer interactions of small groups, and providing technical advice (Lin et al., 2011). Finally, both the teacher and the learners reflect on SI (Hermawan et al., 2017). 


\section{Practical work}

Practical work is about learners handling objects (Lunetta et al., 2007), while Abrahams (2011) argues that it is about doing things with objects, describing and explaining what they observe and making sense of it. Some teachers have not used practical work to enhance learners' object handling and develop learners' ideas. Many use practical work as a cookbook (Erduran et al., 2020) where learners follow instructions with no understanding. It is no wonder this teaching style is imbalanced (Cullinane et al., 2019). A study in New Zealand showed practical work should be open and investigative (Haigh et al., 2005). Most science teachers believe practical work is essential to science teaching and learning ( $\mathrm{Ng}$ \& Nguyen, 2006). In South Africa, practical work is perceived as hands-on and mind-on activities (Ramnarain \& Schuster, 2014). It implies that learners manipulate objects, observe various aspects, and use their thinking processes to assemble apparatus and develop many skills (Sedumedi, 2017).

\section{Inquiry}

Smith et al. (2007) contend inquiry is open-ended active learning. Learners identify questions, design and conduct investigations, search and gather information, analyse and interpret data, develop predictions, explain models based on evidence, consider alternative explanations, and use mathematics aspects of the inquiry. These features suggest that inquiry-oriented instruction enables learners to gain a deep understanding of science concepts (Tal et al., 2006). During the inquiry, learners develop and utilise scientific knowledge to enhance their conceptual understanding (Schwartz et al., 2004). Capp et al. (2016) illustrate three knowledge levels teachers can engage learners in inquiry: 1) vague where teachers use descriptions without dimensions, 2) less structured where teachers describe salient dimensions exemplified by questioning and investigating, and 3) more structured where teachers describe less-salient dimensions exemplified by questioning, investigating, interpreting data, experimental evidence, argumentation, communicating, and modelling as part of the eight practices for investigations (Chen \& Terada, 2021; National Research Council [NRC], 2012). Williams (2020) argues that learners use gestures and tactile modes to make sense of science content during the inquiry. Inquiry is an effective means of acquiring multiple skills (Alpaydin, 2017), understanding the nature of science (Gaigher et al., 2014), and engaging learners in doing science (Ramnarain \& Hlatswayo, 2018). It seems easier said than done because Marshall et al. (2016), using 1222 teachers' self-reported research, shows that only $38.7 \%$ enacted inquiry teaching, while Capps and Crawford (2013) found that out of 26 observed lessons, only four lessons enacted inquiry. It suggests that teachers have a limited understanding of inquiry (Capp et al., 2016).

\section{Scientific Investigations}

SI includes raising questions, planning and carrying out learning activities, making observations, using practical skills, analysing data, looking for patterns, explaining and predicting, and developing creativity (Gott et al., 2009). During SI, learners manipulate objects as part of practical work and search for more information from various sources as a way of inquiry (Williams, 2020). Therefore, SI is neither inquiry nor practical work alone, but it includes both inquiry and practical work (Figure 1).

SI is an integral part of science teaching and learning. South African Curriculum Assessment Policy Statement (CAPS), Life Sciences demands teachers to engage learners in SI (Department of Basic Education, 2011). According to Manz (2020), investigations involve:

- developing empirical systems,

- getting a grip on empirical systems,

- determining,

- defining and operationalising data as "evidence," and

- making sense of the results of empirical systems that have been neglected.

Furthermore, Manz (2020) proposes an alignment between phenomenon, empirical model, data model, and explanatory model, which goes a long way to improve science teaching and learning. Thus, the focal point for teaching investigations is to engage learners in explaining their findings. However, many teachers have challenges implementing SI (Ramnarain, 2014) and assessing SI. For example, Umalusi (2018) stated that some teachers awarded a full mark or half a mark of some practical questions that would be awarded no mark. Self-reported research on teachers' enactment of SI shows high values that may not reflect the actual practice (Marshall et al., 2009). It implies that the teachers'

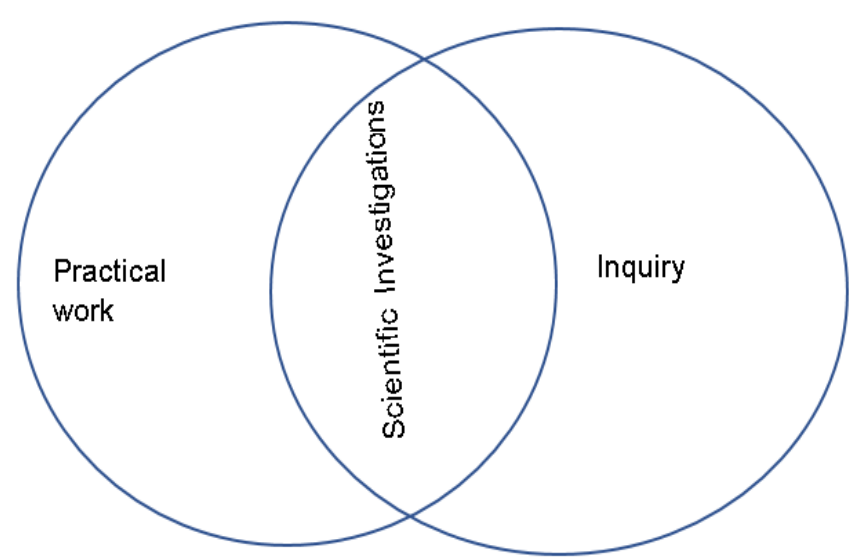

Figure 1. Scientific investigation model (adapted from Ramnarain \& Kibirige, 2010) 
understanding of SI is limited. Also, it may be because of their beliefs and attitudes (Ramnarain \& Hlatshwayo, 2018) and conceptions of the Nature of Scientific Inquiry (NOSI) (Dudu, 2014). Weiss et al. (2003) showed that SI practice decreased from $15 \%$ in primary to $2 \%$ in the high school, suggesting that few teachers engage learners in SI at high school level, which could be related to teachers' perceptions of SI. Few studies have reported on teachers' perceptions regarding SI, and there are few studies regarding SI practice. Therefore, this study investigated teachers' perceptions regarding SI and their classroom SI practices. Three questions and one hypothesis guided the study: 1) What are teachers' perceptions regarding practical work, inquiry and SI? 2) What activities do learners engage in during SI? and 3) What are teachers' challenges when facilitating SI? The hypothesis was: Teachers from differently resourced schools do not have different perceptions of practical work, inquiry, and SI.

\section{METHODOLOGY}

Researchers used an exploratory sequential design (Creswell \& Plano Clark, 2018) with two phases: The qualitative and the quantitative. The exploratory sequential design was necessary because during interviews teachers had challenges distinguishing between inquiry, practical work and Scientific Investigations. Against this backdrop, the researchers sought to use a mixed methods approach using deductive and inductive inquiry. The mixed methods approach drew strengths and weaknesses of quantitative and qualitative paradigms (Johnson \& Onwuegbuzie, 2004). Thus, qualitative phase data were used in designing the questionnaire for the quantitative phase (Creswell \& Plano Clark, 2018).

In the qualitative phase, interviews were used to probe teachers' perceptions of SI and classroom observations were used to identify teachers' and learners' actions during SI lessons. Four questions used regarding teachers' perceptions of SI were: 1) What do you understand by practical work, inquiry and SI? 2) How do you comply with the CAPS requirements in facilitating SI? 3) How often do you involve learners in SI? and 4) What constraints do you encounter when facilitating SI, and how do you overcome them? Similarly, three questions on their classroom practices posed to teachers were: 1) How do you describe your confidence in facilitating SI? 2) How do you describe your roles in your classroom when facilitating SI? and 3) What are the learners' roles during SI?

Three experts checked the researcher-designed interview questions for face validity, and their recommendations were used to improve the questions. Interviews were audio-taped for 45 minutes per session, and this time was enough to gather the needed information (Chauncey, 2014). Researchers used the member-check method to ensure trustworthiness (Rolfe, 2006). The researchers designed a checklist with 12 items to "provide the here-and-now experiences in depths" (Lincoln \& Guba, 1985, p. 273). The second author observed four lessons for each of the 10 participants. Data from interviews were analysed thematically (Creswell \& Clark, 2018) (Appendix B and Appendix C). To apply deductive analysis, the researchers used a codebook based on the research questions (Appendix D). The researchers formed codes using a constant comparison of codes, looking for similarities and differences to create sub-themes (Strauss \& Corbin, 1990), and finally, similar sub-themes generated one major theme (Cilesiz, 2009). Data from observations were analysed using the frequency of compliance and non-compliance with SI practices (ICAP) (Chi \& Wylie, 2014) and K-12 Science Standards (National Research Council [NRC], 2012).

In the quantitative phase, a survey questionnaire with a four-point Likert scale (Likert, 1932) was designed by researchers. Researchers used literature on inquiry and answers from interviews to develop the questionnaire. The questionnaire consisted of 2 sections. Section A dealing with teachers' perceptions regarding SI were coded as $1=$ Strongly Disagree (SD); $2=$ Low Disagree (LD); 3=Low Agree (LA); and 4=Strongly Agree (SA). Similarly, Section B regarding teachers' classroom practices responses were coded as $1=$ Strongly Disagree (SD); 2=Low Disagree (LD); 3=Low Agree (LA) and $4=$ Strongly Agree (SA). A panel of three research experts at the University analysed the survey questionnaire for both face and content validity (Sangoseni et al., 2013). The initial survey questionnaire consisted of 160 items. After their analysis, some items were removed, leaving 117 that measured the intended constructs (Bolarinwa, 2016). Eighty-one questions were on perceptions and facilitation. Ten teachers participated in a pilot study, and Cronbach's alpha reliability for section $A=0.70$ and section $B=0.78$ were obtained with an overall Cronbach's alpha of 0.74 , which was suitable for the study (George \& Mallery, 2003). The population was 245 Grade 11 Life Sciences educators in the Capricorn District, South Africa. The researcher inserted 245 into the Rao Software on the internet, which uses the following formula to calculate the sample size $N$, and the margin of error $\boldsymbol{\varepsilon}$ :

$$
N=\frac{z 2 \times \hat{\mathrm{A}}(\mathbf{1}-\hat{\mathrm{A}})}{\boldsymbol{\varepsilon}^{2}}
$$

where $\mathbf{z}$ is the $\mathbf{z}$ score- $(1.96)^{2}$ at $95 \%, \boldsymbol{\varepsilon}$ is the margin of error- $(0.063)^{2}, \mathbf{1}$ is the populations- $245, \mathbf{N}$ is sample size - ?, and $\hat{\mathbf{A}}$ is the population proportion-(assume $50 \%$, which is 0.5).

A sample size of 149 was obtained with a margin of error of $6.3 \%$ at a confidence level of $95 \%$. Therefore, 150 educators (males 112 and females 38) with teaching experiences ranging from 3 to 28 years were randomly 
Table 1. Teachers' biographic data according to school resource category

\begin{tabular}{|c|c|c|c|}
\hline $\begin{array}{l}\text { Interview } \\
\text { participant } \\
\text { gender \& number }\end{array}$ & $\begin{array}{l}\text { Resource } \\
\text { category }\end{array}$ & $\begin{array}{l}\text { Number } \\
\text { (Male: } \\
\text { Female) }\end{array}$ & $\begin{array}{l}\text { Teaching } \\
\text { experience } \\
\text { (range) }\end{array}$ \\
\hline & Qualitative (10) & \multicolumn{2}{|c|}{ Quantitative (150) } \\
\hline $\begin{array}{l}\text { Male 4; } 7 \\
\text { Female } 5\end{array}$ & $\begin{array}{l}\text { Poorly/Under- } \\
\text { resourced }(\mathrm{A})\end{array}$ & $\begin{array}{c}50(32: \\
18)\end{array}$ & $\begin{array}{c}\text { Male }(6-21) \\
\text { Female }(3-18)\end{array}$ \\
\hline $\begin{array}{l}\text { Male } 6 ; 3 \\
\text { Female 9; } 10\end{array}$ & $\begin{array}{l}\text { Moderately } \\
\text { resourced (B) }\end{array}$ & $\begin{array}{c}50 \text { (39: } \\
11)\end{array}$ & $\begin{array}{c}\text { Male }(4-28) \\
\text { Female }(3-21)\end{array}$ \\
\hline $\begin{array}{l}\text { Male 8; } 1 \\
\text { Female } 2\end{array}$ & $\begin{array}{l}\text { Well-resourced } \\
\text { (C) }\end{array}$ & $\begin{array}{l}50 \text { (41: } \\
9)\end{array}$ & $\begin{array}{c}\text { Male }(6-25) \\
\text { Female }(3-12)\end{array}$ \\
\hline
\end{tabular}

selected. Three categories of schools had equal numbers. 50 for well-resourced, 50 for moderately-resourced and 50 for under-resourced schools (Table 1).

The second researcher distributed the questionnaires and collected them at an agreed time. Data were analysed using descriptive statistics (percentages, means, standard deviations) and inferential statistics: $t$ test, Analysis of Variance (ANOVA). A $t$-test was to ascertain differences between items of each section, while ANOVA was to identify differences in perceptions between and within groups. In all quantitative analyses, SPSS version 20 was used as a tool.

\section{RESULTS}

The results show teachers had various perceptions regarding SI and their classroom practices of facilitating SI differed significantly. Teachers had different perceptions regarding practical work, inquiry and SI. Most teachers engaged learners in listening (passive), demonstrations, and few conducted practical work. Most teachers narrated SI procedures to learners, and learners did not predict or hypothesize. Teachers from differently resourced schools differed in perceptions regarding facilitating SI. So, the researchers reject the hypothesis that Teachers from differently resourced schools do not have different perceptions of practical work, inquiry and SI. All teachers admitted there were limitations in facilitating SI. Detailed results are presented according to the three research questions.

\section{Research Question 1: What are Teachers' Perceptions Regarding Practical Work, Inquiry, and SI?}

\section{Qualitative}

Theme 1: Different perceptions regarding practical work, inquiry and SI: Seven out of ten teachers from the qualitative section perceived practical work as any purposeful, class-based, hands-on activity characterised by manipulating objects and following a prescribed method. These teachers perceived hands-on activities to be confined to practical work and not SI. Teacher 5, for example, explained:
"Practical work needs investigators to be hands-on to achieve a specific goal. SI and inquiry can be done without being hands-on."

Other teachers regarded any hands-on activity to be SI. Teacher 1, for example, hinted:

\section{"As long as learners manipulate objects, they are doing SI and are happy about it."}

Teachers perceived inquiry as informal, where oral questioning was used to gather information. Seven teachers considered inquiry to refer to oral questions. Teacher 8:

"With inquiry, you are looking at a topic; you go around and ask people about the topic and get the perfect answer to solve whatever you are inquiring. In inquiry, learners do not even use their hands."

Seven teachers perceived SI as fulfilling the Continuous Assessment (CASS) requirements prescribed in the Life Sciences CAPS policy document. Educator 10 explained:

"Basically, I carry out three scientific investigations per annum for the sake of assessment in order to have CASS marks as expected by the Department of Education."

\section{Quantitative}

This quantitative section presents the findings collected using Likert four scale questionnaire. Two hundred questionnaires were issued out to Grade 11 Life Sciences educators in the Capricorn District of the Department of Education to respond. A total number of 150 Likert four-point scale questionnaires were filled and collected. Educators in the quantitative section of the study presented a variety of perceptions of scientific investigations, practical work, and inquiry. The perceptions are presented in Figures 2-3.

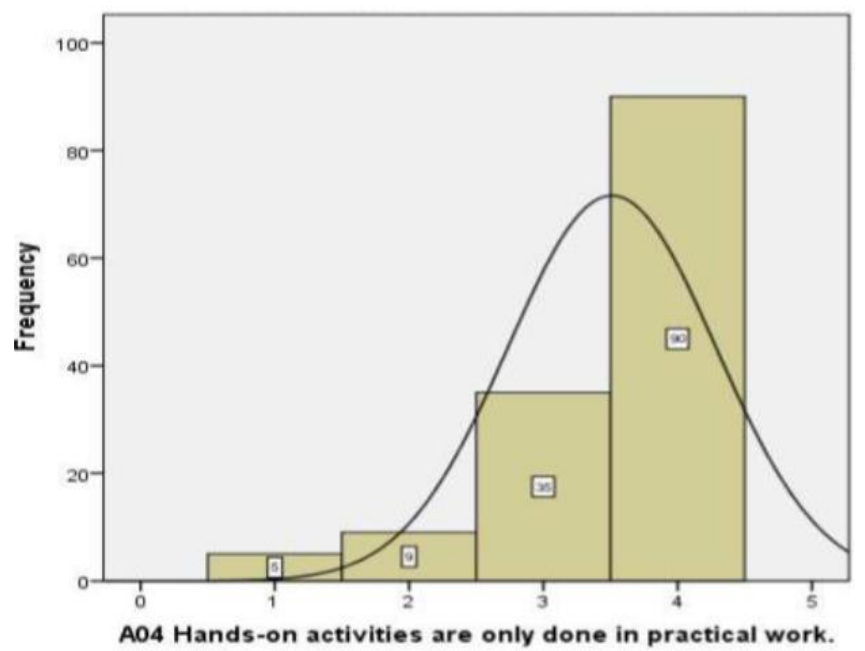

Figure 2. Teachers' perceptions of practical work-1 


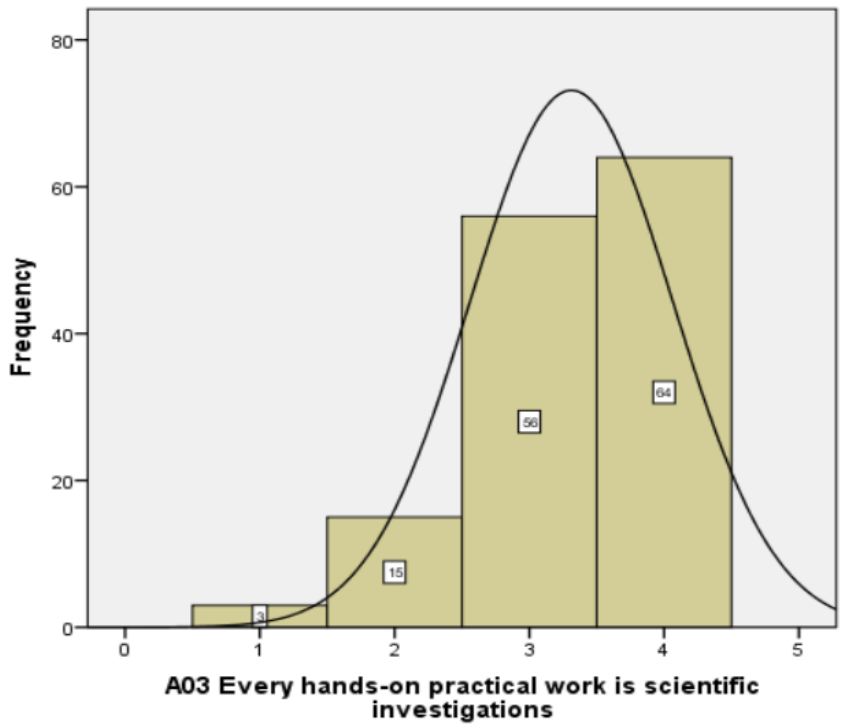

Figure 3. Teachers' perceptions of practical work-2

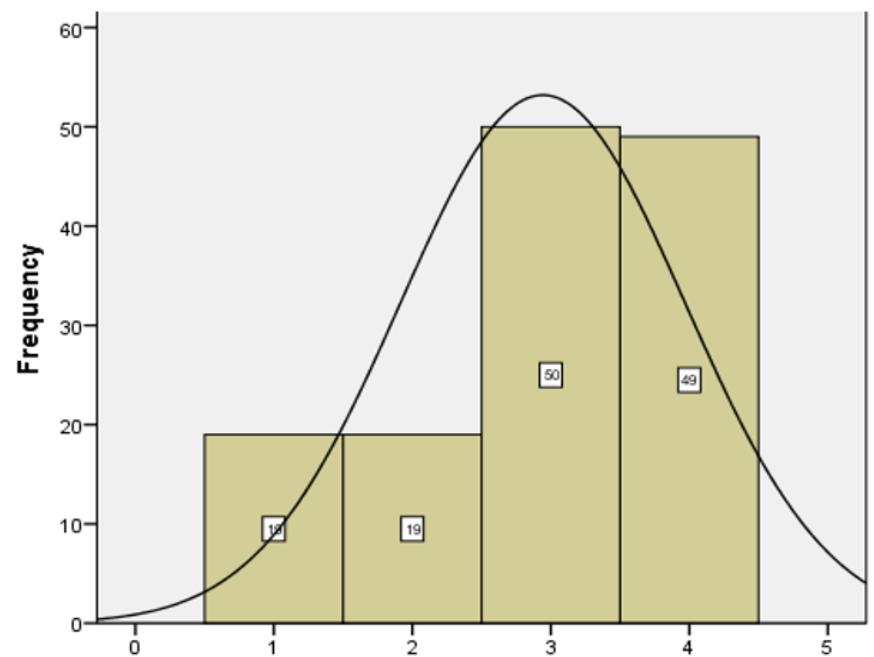

Figure 4. Teachers' perceptions regarding inquiry teaching and learning

Figure 2 shows that $125(84 \%)$ teachers (mean=3.51; $\mathrm{SD}=.75)$ perceived that hands-on activities were confined to practical work only. The distribution curve in Figure 3 shows that 120 teachers (80.5\%) perceived every hands-on practical work as SI (mean $=3.31$; $\mathrm{SD}=.77)$.

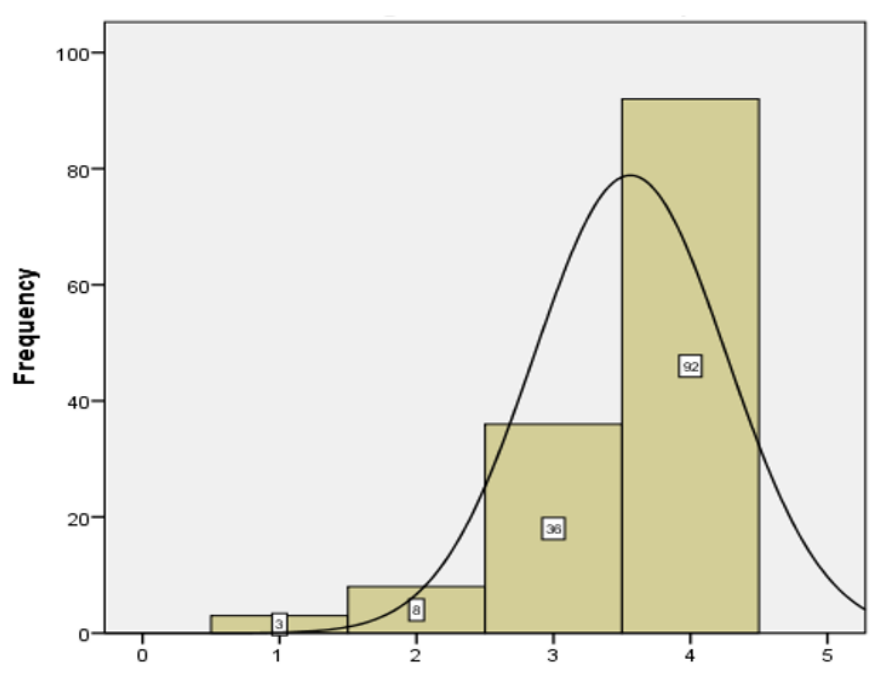

Figure 5. Teachers' perceptions of scientific investigations

\section{Educators' perceptions of inquiry}

Teachers were asked to gauge their perceptions regarding inquiry teaching and learning (Figure 4). Figure 4 shows that $99(66.00 \%)$ of the participants (mean of $2.94, \mathrm{SD}=1.03$ ) perceived inquiry to be the same as a literature review to gather data, which guided their teaching practice. In contrast, 51 out of $150(34 \%)$ teachers did not hold this view.

Figure 5 shows that 128 out of $150(85.30 \%)$ teachers (mean=3.56; $\mathrm{SD}=.70$ ) held the perception that Scientific Investigations are composed of both practical work and inquiry.

A $t$-test was used to find if there were significant differences between the 'Total Agree' and 'Total Disagree' (Table 2).

The $t$-test results (Table 2) show significant differences amongst teachers' conceptualisation of SI $(t-$ test: $\mathrm{t}=8.81 ; \mathrm{p}=.01)$; inquiry ( $t$-test: $\mathrm{t}=7.04 ; \mathrm{p}=.01)$; practical work ( $t$-test: $\mathrm{t}=-1.69 ; \mathrm{p}=.01)$; and teachers' views of SI facilitation ( $t$-test: $t=5.92 ; p=.01)$.

The differences in teachers' perceptions regarding SI were tested using ANOVA (Table 3). The results in Table 3 show that there were significant differences in perceptions between teachers from well-resourced schools $F(5.67), \mathrm{p}=.04$ and moderately resourced schools

Table 2. t-test independent results on teachers' conceptualisation and facilitation of SI

\begin{tabular}{|c|c|c|c|c|c|c|c|c|}
\hline \multirow[b]{2}{*}{ Statement } & & \multicolumn{6}{|c|}{ Levine's equality of variances } & \multirow{2}{*}{$\frac{\mathrm{p} \text {-value }}{\text { Sig. (2-tailed) }}$} \\
\hline & & Mean & Std. dev. & $\mathrm{F}$ & Sig. & $\mathrm{t}$ & $\mathrm{df}$ & \\
\hline Teachers' & Equal variances assumed & 3.54 & 0.76 & 20.31 & .18 & 4.72 & 194.67 & .00 \\
\hline $\begin{array}{l}\text { conceptualisation of SI, } \\
\text { inquiry, and practical work }\end{array}$ & Equal variances not assumed & 2.97 & 1.0 & & & 4.72 & 220.95 & .00 \\
\hline Teachers' declared & Equal variances assumed & 3.35 & 1.03 & .04 & .84 & 3.00 & 278 & .00 \\
\hline improvisation capabilities & Equal variances not assumed & 2.990 & 1.003 & & & 3.00 & 277.79 & .00 \\
\hline Teachers' conceptualisation & Equal variances assumed & 3.36 & .87 & .39 & .53 & -1.69 & 278 & .01 \\
\hline of practical work & Equal variances not assumed & 3.54 & .83 & & & -1.69 & 277.36 & .01 \\
\hline Teachers' SI facilitation & Equal variances assumed & 3.33 & 0.89 & 35.20 & 0.00 & 5.92 & 278 & .00 \\
\hline views & Equal variances not assumed & 2.51 & 1.36 & & & 5.92 & 240.13 & .00 \\
\hline
\end{tabular}


Table 3. ANOVA test results of teachers' perceptions from differently resourced schools regarding SI

\begin{tabular}{|c|c|c|c|c|c|c|}
\hline \multicolumn{2}{|l|}{$\begin{array}{l}\text { Teachers' school } \\
\text { category }\end{array}$} & $\begin{array}{l}\text { Sum of } \\
\text { squares }\end{array}$ & $\mathrm{df}$ & $\begin{array}{l}\text { Mean } \\
\text { square }\end{array}$ & $\mathrm{F}$ & $\mathrm{p}$ \\
\hline \multirow{3}{*}{$\begin{array}{l}\text { Teachers from well } \\
\text { resourced schools (A) }\end{array}$} & Between groups & .91 & 2 & .46 & \multirow[t]{3}{*}{5.67} & \multirow[t]{3}{*}{.04} \\
\hline & Within groups & .48 & 6 & .08 & & \\
\hline & Total & 1.40 & 8 & & & \\
\hline \multirow{3}{*}{$\begin{array}{l}\text { Teachers from } \\
\text { moderately resourced } \\
\text { schools (B) }\end{array}$} & Between groups & 1.00 & 3 & .33 & \multirow[t]{3}{*}{3.36} & \multirow[t]{3}{*}{.04} \\
\hline & Within groups & 1.58 & 16 & .11 & & \\
\hline & Total & 2.58 & 19 & & & \\
\hline \multirow{3}{*}{$\begin{array}{l}\text { Teachers from under } \\
\text { resourced schools }(\mathrm{C})\end{array}$} & Between groups & .40 & 5 & .08 & \multirow[t]{3}{*}{.43} & \multirow[t]{3}{*}{.83} \\
\hline & Within groups & 3.38 & 18 & .19 & & \\
\hline & Total & 3.78 & 23 & & & \\
\hline
\end{tabular}

Table 4. Tukey HSD test for teachers' statements on SI, inquiry, practical work, improvisation, and declared views

\begin{tabular}{lccc}
\hline Variables & Mean difference & Std. error & Sig. \\
\hline Teachers from well-resourced schools (A) & -.78 & .23 & .04 \\
Teachers from under resourced schools (C) & -.40 & .23 & .23 \\
Teachers from moderately resourced schools (B) & .78 & .37 & .23 \\
Teachers from poorly resourced schools (C) & -.57 & .19 & .03 \\
Lack of resources is not a hindrance (A) & -.50 & .19 & .05 \\
Improvisation skills solve lack of resources problems (B) & & \\
\hline
\end{tabular}

$\mathrm{F}(3.36), \mathrm{p}=.04$, but not for teachers from poorly resourced schools $\mathrm{F}(0.43), \mathrm{p}=.83$.

Furthermore, Tukey Honest Significant Differences (HSD) was used to determine the differences between the variables (Table 4 ).

Table 4 shows teachers from differently resourced schools differed significantly in their perceptions: Wellresourced and poorly resourced (AC), and moderately and poorly resourced (BC), but not well resourced and moderately resourced (AB).

\section{Research Question 2: What Activities Do Learners Engage in During SI?}

\section{Qualitative}

Classroom observations were conducted by the second researcher using some practices from the (National Research Council [NRC], 2012) like asking questions; developing and using models; planning and carrying out investigations; analyzing and interpreting data; constructing explanations; engaging argument from evidence; evaluating findings and communicating. These practices were noted as compliance and noncompliance (Appendix A). The results show that 11 teachers out of 12 did not adequately conduct practical work with non-compliance ranging from $75 \%$ to $100 \%$. Teachers' frequency compliance with SI practices ranged from $0 \%$ to $70 \%$ with the majority $(66.67 \%)$ rating less than $30 \%$. In all the lessons observed, teachers did not adequately facilitate SI as stipulated in the curriculum.

\section{Quantitative}

From the survey questionnaire, teachers' perceptions regarding a) creating opportunities for learners' autonomy when designing experiments, b) learning

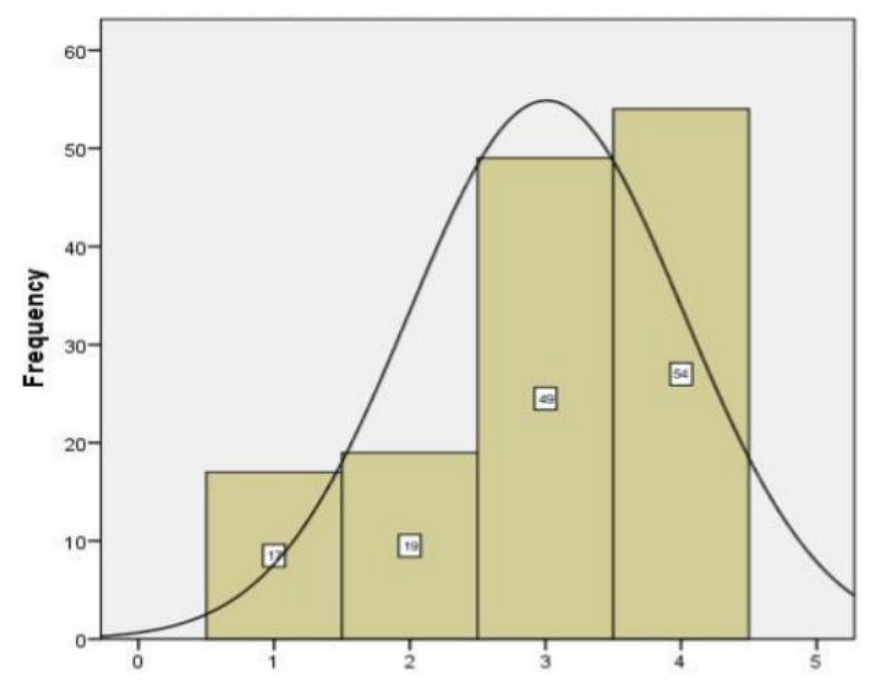

Figure 6. Teachers' perceptions of creating opportunities for learners' autonomy when designing experiments

scientific investigation theoretically, and c) demonstrations during Scientific Investigations are indicated in Figures 6-8.

Figure 6 shows that 103 out of 150 (68.6\%) teachers perceived they created opportunities for learners' autonomy when designing experiments. Figure 7 shows that 110 of the $150(73.3 \%)$ teachers taught scientific investigations using narratives for learners to write the main points in their textbooks. There were no hands-on activities. Figure 8 shows that $83(60.1 \%)$ teachers demonstrated during Scientific Investigations. 


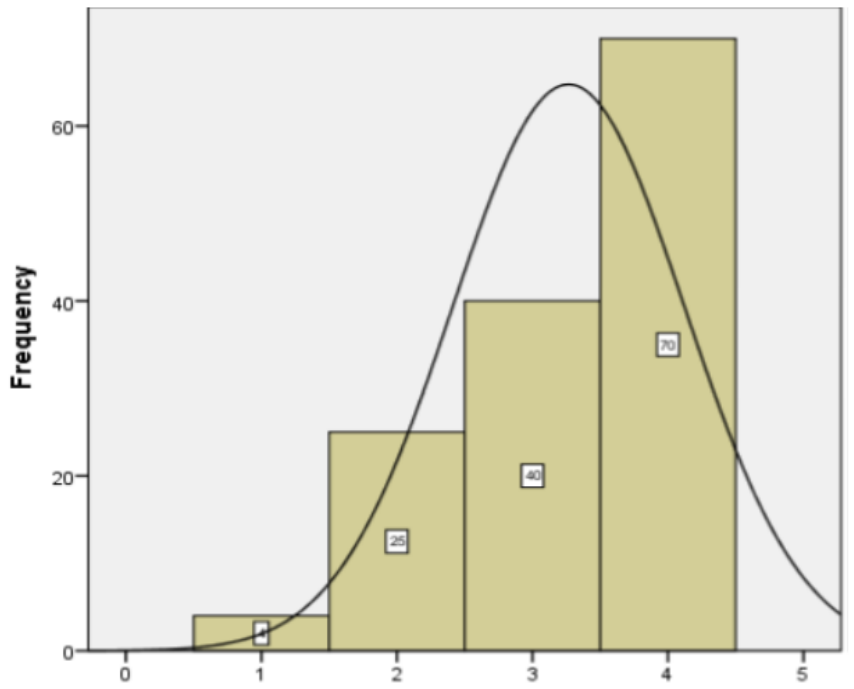

Figure 7. Teachers' perceptions of learning scientific investigation theoretically

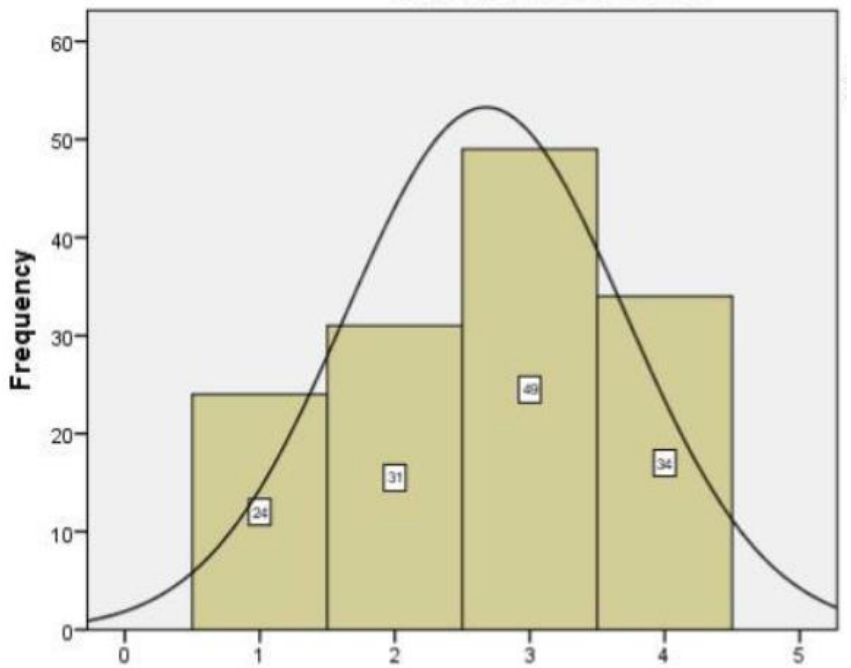

Figure 8. Teachers' perceptions of demonstrations during scientific investigations

\section{Research Question 3: What are Teachers' Challenges in Facilitating SI?}

\section{Qualitative}

Theme 2: Teachers' lack of skills to facilitate SI: Seven out of $10(70 \%)$ teachers indicated were not confident with facilitating SI, which rendered their efforts to facilitate SI futile. A few examples illustrate that sentiment:

"I am not equipped with the skills of doing SI. I need skills and knowledge to involve learners in SI." Teacher 4 .

"I cannot say I was empowered to improvise. I did not get proper guidance to do SI. I am not equipped with the skill of practically assessing." Teacher 10 .
"Normally I take the one that is provided by the Department of Education in the pacesetters. This is because I enjoy teaching more than doing SI." Teacher 2 .

Theme 3: Inadequate resources to facilitate SI: All seven teachers from moderately and poorly resourced schools stated that they lacked resource to facilitate SI. Examples of a few teachers demonstrate this challenge:

"We lack resources, being under-skilled, and lack space too. Sometimes we just emulate the investigation, not really doing it." Educator 5 .

"There are not enough facilities. I am not equipped with the skill of practically assessing learners' level of science process skills acquisition during SI. That is why I usually follow programmed SI." Educator 6.

"Our laboratory is used as a store room for science materials. There is a problem of lack of space. Sometimes I am forced to do scientific investigation in classroom setting instead of laboratory. So learners cannot do investigations practically. What if learners get hurt or break apparatus? That is why I demonstrate." Educator 8.

"Sometimes we group learners to share the few apparatuses that we have. This makes SI costly in terms of time/duration. Big classes. Apparatus is very expensive too. We do not know what to do to teach investigations in these conditions." Teacher 9.

\section{Quantitative}

Teachers perceived science content knowledge as enough to enable them to facilitate SI.

Figure 9 shows that 51 teachers (34\%) indicated that content knowledge only was necessary for teaching SI successfully. It implies that most teachers did not view knowledge as the only requirement for engaging learners in SI. Other teachers showed they needed science process skills and scientific knowledge to facilitate scientific investigations (Figure 10), where most educators 132 (88\%) perceived science process skills and content knowledge as requisites for facilitating SI.

\section{DISCUSSION}

The study explored teachers' perceptions regarding SI and their experiences in facilitating SI from well, moderately, and under-resourced schools. The results show significant differences between teachers' perceptions regarding SI. Teachers had challenges in distinguishing between practical work, inquiry, and investigations. Teachers' roles in facilitating SI were not 


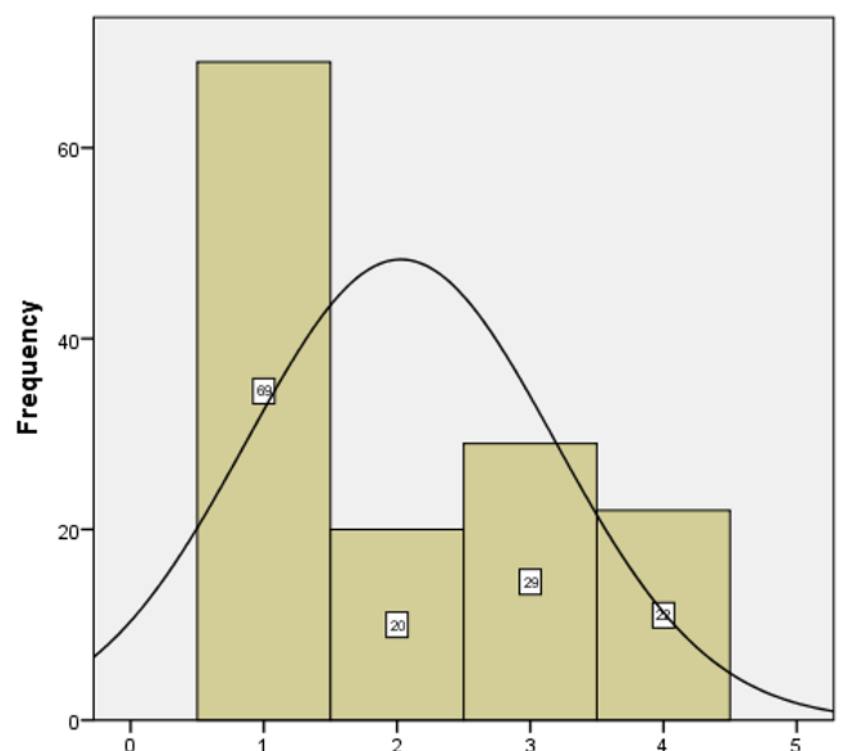

Figure 9. Teachers' perceptions regarding science knowledge as the requirement for successful facilitation of scientific investigations

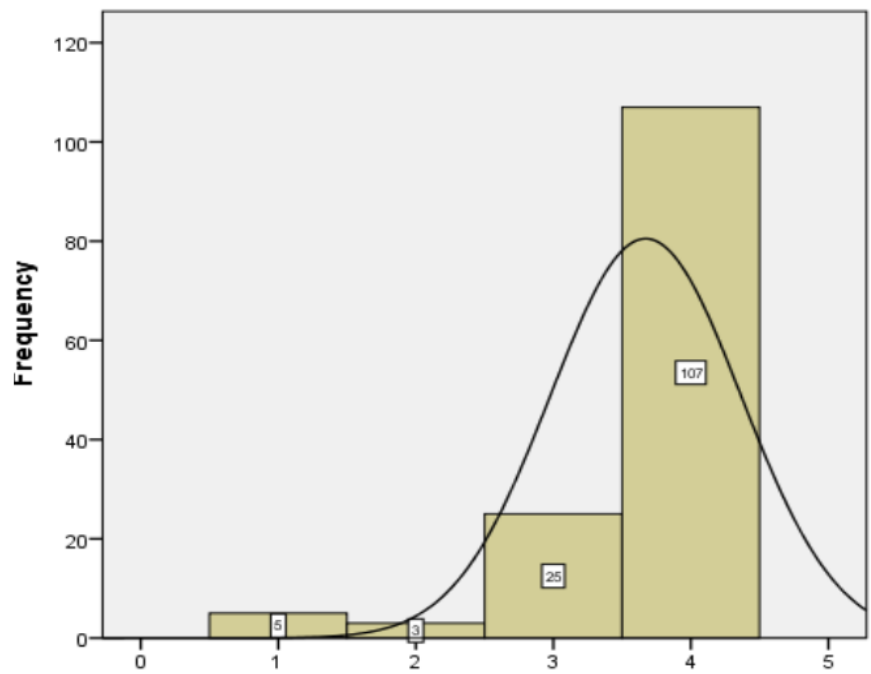

Figure 10. Teachers' need for both science process skills and content knowledge

clear in all the three categories of schools: poorly, moderately and well resourced. Teachers used narratives, demonstrations, worksheets to represent SI activities. The teachers' classroom practices are not "doom and gloom" because a few teachers used digital devices to engage learners with SI aligning with the 4IR.

\section{Research Question 1: What are Teachers' Perceptions Regarding Practical Work, Inquiry, and SI?}

Qualitative and quantitative results show that teachers had diverse perceptions regarding practical work, inquiry, and SI. Most teachers from qualitative results perceived practical work as any purposeful, class-based, hands-on activity and perceived every hands on practical work to denote SI (Figures 2-3). Although many (68.6\%) teachers in quantitative results perceived SI as engaging learners in designing experiments, (60.1\%) of them used demonstrations (Figures 7-8). These results are not surprising because the introduction of CAPS in South African schools resulted in tensions between the curriculum designers and the teachers (Tsakeni, 2018). Teachers had a challenge implementing the curriculum because of a lack of skills. Participants from interviews testified they lacked the skills to implement SI. Interviews and questionnaires show teachers did not have a similar understanding of SI because teachers gave different responses: it was the same as inquiry; it was the same as using worksheets and hands-on. $66.0 \%$ of the teachers perceived inquiry as similar to the literature review (Figure 4), suggesting a misunderstanding of SI. $85.30 \%$ perceived SI as composed of practical work and inquiry (Figure 5). These results contrast the common use of both practical work and inquiry in class, and are not surprising because Marshall et al. (2009) state that teachers had challenges implementing SI.

Similarly, during observations, most teachers $(70 \%)$ (Appendix A) used demonstrations to teach science; using demonstrations was their easy option because of limited school resources. Therefore, learners passively observed teacher demonstrations. The teachers' use of demonstrations agrees with Bantwini's (2009) finding that the under-resourced environment, in many developing countries, compelled teachers to resort to non-SI teaching approaches. Also, it was noted that little effort was placed on improvisation using locally available resources, especially in life sciences. This observation contrasts with what was observed in Ghana, where teachers used recyclable materials to teach science (Yeboah et al., 2016).

Some teachers used recorded videos to teach SI. They explained that the recorded videos were a viable option because of the lack of resources in schools. It becomes imperative now in the 4IR for teachers to use digital technology like the internet, three-dimensional printing - 3D, and Computer Simulations (CS) in science teaching (Kayembe \& Nel, 2019). For instance, a study by Kibirige and Tsamago (2019) in South Africa concluded that CS is an effective method of teaching science. Thus, using digital technology in topics like evolution and environmental issues where manipulation of materials may not be possible can be effective for the learners to construct knowledge mentally. The only challenge is that the old generation of teachers does not easily catch up with digital technology in South Africa (Mavhunga et al., 2016). It suggests that teachers' abilities of using digital technology in teaching science were limited (Govender \& Skea, 2015), and there is a need to improve teachers' proficiencies (Dlamini \& Mbatha, 2018) to meet the demands of the 4IR (Williams, 2017).

A significant percentage $(66.0 \%)$ of teachers viewed inquiry as a detailed formal search of information about a phenomenon from different sources and media (Figure 4), while qualitative data shows no clear pattern. 
Teachers' perceptions in three different categories of schools: poorly, moderately, and well-resourced were significantly different between teachers from poorly resourced and teachers from moderate and wellresourced schools (ANOVA, Table 4), Tukey HSD (Table 5). Researchers reject the hypothesis that teachers from differently resourced schools do not have different perceptions of practical work, inquiry, and SI. It means that the availability of resources affected the teachers' perceptions regarding SI. This observation concurs with Govender and Skea (2015), who reported differences in teachers' perceptions regarding e-safety in wellresourced and poorly resourced schools of KwaZuluNatal in South Africa. This finding contrasts with some teachers' perceptions from well-resourced schools that did not use the resources because of a lack of skills. For instance, one teacher indicated the laboratory was used as a store, suggesting that learners were not exposed to inquiry learning. It is most likely that teachers did not have the skills to use the resources to teach SI. The lack of inquiry teaching was contrary to Smith et al. (2007), who suggest that inquiry should be open-ended where learners gather information from resources.

The teachers' perceptions of SI influence their classroom practices. Most teachers did not include inquiry and practical work as part of SI in their classroom practices. They believed that hands-on activities were confined to practical work and excluded inquiry and SI (Figure 2). These perceptions contrast the SI concept, where SI intersects practical work and inquiry (Figure 1) (Ramnarain \& Kibirige, 2010). Doing SI includes inquiry and practical work, respectively. It is no wonder some teachers had confusing ideas regarding SI and did not help learners perform experiments; instead, they narrated how experiments are done and told the learners the expected results. Narrating experiments to learners defeats the purpose of SI, which is to equip learners with science process skills. According to Malathi and Rohini (2017), effective teachers use SI to teach science. Therefore, teachers must understand what constitutes SI to improve their classroom practice.

Teachers pointed out challenges in facilitating SI emanating from a lack of skills and inadequate school infrastructure. They assessed learners' SI skills using pen and paper, which may not assess all SI skills like handling apparatus, measuring and recording data (Hein \& Lee, 2000). It suggests that teachers had challenges in specific areas of SI (Tilling, 2018). Ramnarain (2014) reported a similar practice in which teachers taught learners to memorise and reproduce materials in the tests. Teachers' inadequate skills can be attributed to South Africa's past challenges, especially teachers from disadvantaged communities who were trained during Apartheid, did not experience SI. Teachers teach the subject the way they were taught. It implies that teachers hold on to the instructional methods they witnessed as learners (Mazur, 2009). It is not surprising that teachers put little effort into how they teach the content (Sierra-Llorente et al., 2018). Teaching for memorisation is a global challenge reported in the literature. Teacher 3, for example, used to share the past assessment questions with learners. It is the practice that Dogan (2020, p. 21) calls 'Teaching to test', which enables learners to score high marks in the pen-paper SI assessment activities not because they have mastered the SI skills, but because they have practised beforehand how to answer questions. This challenge corroborates Ramnarain (2011) and Tsakeni (2018), who identified inadequate capacities to teach science using SI. The results also highlight that teachers who teach in wellresourced schools with good infrastructure and science equipment could not engage learners in SI. Similar findings are reported by Osborne (2015), who showed that some teachers did not engage learners in hands-on activities despite resource availability. Failure to engage learners in hands-on activities contradicts the Social Constructivism theory constructs, suggesting learners' autonomy when they manipulate resources to learn (Ramnarain, 2020).

\section{Research Question 2: What Activities Do Learners Engage in During SI?}

While many teachers perceived what they did in class engaged learners in SI, teacher observations showed the contrary because many teachers engaged learners in demonstrations and very few hands-on tasks. Our observation agrees with Capps and Crawford (2013), who found only four lessons out of 26 to comply with inquiry and Marshall et al. (2016), who found that only $38.7 \%$ of teachers enacted inquiry. A high frequency of non-compliance to SI practices was observed. In addition, there were no learner activities for planning investigations in all the practical lessons. It suggests that teachers' perceptions did not translate into practice and that teachers had insufficient knowledge of SI. This finding concurs with Capps and Crawford's (2013) observation that teachers with insufficient inquiry knowledge did not enact SI well. It is not clear why there is a discrepancy between teachers' perceptions of SI facilitation in well and moderately resourced schools compared to poorly resourced schools, and this needs further study.

\section{Research Question 3: What are Teachers' Challenges in Facilitating SI?}

The teachers' challenges were lack of resources, small classrooms (not enough space), and huge workloads. Other challenges included a lack of self-assessment of content knowledge because only 34\% contended that they lacked the knowledge to teach SI. It implies that many teachers did not view knowledge as the only prerequisite for engaging learners in scientific investigations. Many teachers (92.8\%) (Figure 6) 
perceived knowledge of the science process necessary to facilitate SI. Their challenges were that few exhibited such knowledge when observed in practice. These observations corroborate Capp et al. (2016), who found that $60 \%$ of the teachers could not describe activities that constituted inquiry. This observation challenges the Next Generation Science Standards (NGSS) principles, which include questioning, investigating, interpreting data, experimental evidence, using mathematics and computational thinking, argumentation, communicating, and modelling (Chen \& Terada, 2021; National Research Council [NRC], 2012), based on ICAP (Chi \& Wylie, 2014). Therefore, there is a need to improve teachers' abilities to apply them easily.

Finally, as observed, the lack of term and annual SI lesson plans indicates teachers did not conduct SI as prescribed in CAPS (Department of Education, 2011). They used methods like narrating and showing how experiments are done. A similar finding involving learning science without manipulating objects has been reported (Kazeni \& Onwu, 2013). The researchers linked their observation of non-compliance with the curricula to teachers' divergent perceptions regarding SI. It implies that learners were assessed practical skills using pen and paper examinations and explained procedures of experimenting without doing the actual experiments, which is not a true reflection of their SI skills.

\section{CONCLUSIONS}

The study explored teachers' perceptions of SI and their experiences of facilitating SI and showed that teachers had various perceptions regarding the inquiry, practical work, and SI. These varied perceptions guided teachers' actions, where some did few experiments for compliance, demonstrated experiments, and others narrated science experiment procedures. The study further established teachers' challenges in facilitating SI as inadequate skills and inadequate school resources. Teachers from well-resourced and moderately resourced schools had similar perceptions regarding SI implementation.

\section{Limitations to the Study}

The limitation of the study was that it used a small geographical area in Limpopo. In addition, the study dealt with Life Science teachers. More studies are needed to explore teachers' practices of facilitating SI in other science subjects.

Author contributions: All authors have sufficiently contributed to the study, and agreed with the results and conclusions.

Funding: No funding source is reported for this study.

Acknowledgements: The researchers acknowledge the courtesy of teachers and the Department of Education.

Declaration of interest: No conflict of interest is declared by authors.

\section{REFERENCES}

Abdoola, F., Flack, P. S., \& Karrim, S. B. (2017). Facilitating pragmatic skills through role-play in learners with language learning disability. South African Journal of Communication Disorders, 64(1), 112. https:/ / doi.org/10.4102/ sajcd.v64i1.187

Abrahams, I. (2011). Practical work in secondary science: A minds-on approach. London: Continuum.

Adofo, S. (2017). Teachers' perceptions about inquiry in science education [Master thesis, University of Eastern Finland]. https://erepo.uef.fi/bitstream/ handle/123456789/18647/urn_nbn_fi_uef20170914.pdf

Alebiosu, K. A. (2005). Utilising selected informal science experiences to teach science in inquiry-centred Nigerian classrooms. African Education Review, 2(1), 109-117.

https://doi.org/10.1080/ 18146620508566294

Alpaydin, S. (2017). Determining the level of understanding and misconceptions of science teacher candidates about the concepts related to material and its properties. Journal of Education and Practice, 8(30), 25-31. https://files.eric.ed.gov/ fulltext/ED578407.pdf

Bantwini, D. B. (2009). District professional development models as a way to introduce primary school teachers to natural science curriculum reforms in one district in South Africa. Journal of Education for Teaching, 35(2), 169-182. https://doi.org/10.1080/ 02607470902771094

Beck, K., Witteck, T., \& Eilks, I. (2010). Open experimentation on phenomena of chemical reactions via the learning company approach in early secondary chemistry education. Eurasia Journal of Mathematics, Science and Technology Education, 6(3), 163-171. https:/ / doi.org/10.12973/ ejmste/75237

Bolarinwa, O. A. (2016). Principles and methods of validity and reliability testing of questionnaires used in Social and Health Science Researches. Department of Epidemiology and Community Health, University of II, IIorin, Nigeria. https://doi.org/10.4103/ 1117-1936.173959

Capps, D. K., \& Crawford, B. A. (2013). Inquiry-based instruction and teaching about nature of science: Are they happening? Journal of Science Teacher Education, 24(3), 497-526. https: / / doi.org/10.1007/ s10972-012-9314-Z

Capps, D. K., Shemwell, J. T., \& Young, A. M. (2016). Over reported and misunderstood? A study of teachers' reported enactment and knowledge of inquiry-based science teaching. International Journal of Science Education, 38(6), 934-959. https:/ / doi.org/10.1080/09500693.2016.1173261

Chauncey, W. (2014). Interview techniques for UX practitioners. A user-centered design method. Morgan 
Kaufman. https://doi.org/10.1016/B978-0-12410393-1.00003-X

Chen, Y.-C., \& Terada, T. (2021). Development and validation of an observation-based protocol to measure the eight scientific practices of the next generation science standards in K-12 science classrooms. Journal of Research in Science Teaching, 138. https:/ / doi.org/10.1002/tea.21716

Chi, M. T. H., \& Wylie, R. (2014). The ICAP framework: Linking cognitive engagement to active learning outcomes. Educational Psychologist, 49(4), 219-243. https://doi.org/10.1080/00461520.2014.965823

Chi, M. T. H., Adams, J., Bogusch, E. B., Bruchok, C., Kang, S., Lancaster, M., Levy, R., Li, N., McEldoon, K. L., Stump, G. S., Wylie, R., Xu, D., \& Yaghmourian, D. L. (2018). Translating the ICAP theory of cognitive engagement into practice. Cognitive Science, 42(6), 1777-1832. https://doi.org/10.1111/cogs.12626

Cilesiz, S. (2009). Educational computer use in leisure contexts: A phenomenological study of adolescents' experiences at internet cafes. American Educational Research Journal, 46(1), 232-274. https:// doi.org/10.4314/ajesms.v2i2.38590

Creswell, J. W., \& Clark, V. L. P. (2018). Designing and conducting mixed methods research. Thousand Oaks, CA: SAGE.

Crotty, M. (1998). The foundations of social research: Meaning and perspective in the research process. Allen \& Uwin.

Cullinane, A., Erduran, S., \& Wooding, S. J. (2019). Investigating the diversity of scientific methods in high-stakes chemistry examinations in England. International Journal of Science Education, 41(16), 2201-2217.

https:/ / doi.org/10.1080/09500693.2019.1666216

Department of Education. (2008). National curriculum statements-policy documents. Grades 10-12. (General) Life Sciences. Government Printers.

Department of Education. (2011). Curriculum and Assessment Policy Statement. Life Sciences Grades 1012. Government Printers.

Dlamini, R., \& Mbatha, K. (2018). The discourse on ICT teacher professional development needs: The case of a South African Teachers' Union. International Journal of Education and Development using Information and Communication Technology, 14(2), 1737.

Dogan, O. K., (2020). Methodological? Or dialectical? Reflections of scientific inquiry in biology textbooks. International Journal of Science and Mathematics Education, 19, 1563-1585. https:// doi.org/10.1007/s10763-020-10120-7

Dudu, W. T. (2014). Exploring South African high school teachers' conceptions of the nature of scientific inquiry: a case study. South African Journal of
Education, 34(1), 1-9. https://doi.org/10.15700/ 201412120937

Erduran, S., Masri, Y. E., Cullinane, A., \& Ng, Y. P. D. (2020). Assessment of practical science in high stakes examinations: A qualitative analysis of high performing English-speaking countries. International Journal of Science Education, 42(9), 15441567.

https:/ / doi.org/10.1080/09500693.2020.1769876

Fosnot, C. T. (1996). Constructivism: A psychological theory of learning. In C. T. Fosnot (Ed.), Constructivism: Theory, perspectives and practice (pp. 8-33). Teachers College Press.

Gaigher, E., Lederman, N., \& Lederman, J. (2014). Knowledge about inquiry: A study in South African high schools. International Journal of Science Education, 36(18), 3125-3147. https://doi.org/ $10.1080 / 09500693.2014 .954156$

George, D., \& Mallery, P. (2003). SPSS for windows step by step: A simple guide and reference. Boston: Allyn \& Bacon.

Gott, R., Duggan, S., \& Hussain, H. (2009). Research into understanding scientific evidence. http://www.dur. ac.uk/rosalyn.roberts/Evidence/cofev.htm

Govender, I., \& Skea, B. (2015). Teachers' understanding of e-safety: An exploratory case in KZN South Africa. The Electronic Journal of Information Systems in Developing Countries, 70(1), 1-17. https://doi.org /10.1002/j.1681-4835.2015.tb00505.x

Haigh, M., France, B., \& Forret, M. (2005). Is "doing science" in New Zealand classrooms an expression of scientific inquiry? International Journal of Science Education, 27, 215-226. https://doi.org/10.1080/ 0950069042000276730

Hein, G., \& Lee, S. (2000). Assessment of science inquiry. In National Science Foundations (Eds.), Inquiry: Thoughts, views, and strategies for the K-5 classroom (pp. 99-108). http://www.nsf.gov/pubs/2000/ nsf99148/

Hermawan, H., Siahaan, P., Suhendi, E., \& Samsudin, A. (2017). Promoting collaboration skills on reflection concept through multimedia-based integrated instruction. AIP Conference Proceedings 1848, 050009. https:/ / doi.org/10.1063/1.4983965

Huang, H. M., Rauch, U., \& Liaw, S. H. (2010). Investigating learners' attitudes towards virtual reality learning environments: Based on constructivism approach. Computers and Education, 55, 1171-1182. https:/ / doi.org/10.1016/j.compedu. 2010.05.014

Johnson, R. B., \& Onwuegbuzie, A. J. (2004). Mixed methods research: A research paradigm whose time has come. Educational Researcher, 33(7), 14-26. https:/ / doi.org/10.3102/0013189X033007014

Kayembe, C., \& Nel, D. (2019). Challenges and opportunities for education in the fourth industrial 
revolution. African Journal of Public Affairs, 11(3), 7994. https://journals.co.za/doi/pdf/10.10520/EJC19605d342e

Kazeni, M., \& Onwu, G. (2013). Comparative effectiveness of context-based and traditional approaches to teaching genetics: Students' views and achievements. African Journal of Research in Mathematics, Science and Technology Education, 17(12), 50-62. https://doi.org/10.1080/10288457.2013. 826970

Kibirige, I., \& Tsamago, H. E. (2019). Grade 10 learners' science conceptual development using computer simulations. Eurasia Journal of Mathematics, Science and Technology Education, 15(7), 1-17. https:/ / doi.org/10.29333/ ejmste/106057

Leon, J., Medina-Garrido, E., \& Núñez, JL (2017). Teaching quality in math class: The development of a scale and the analysis of its relationship with engagement and achievement. Frontiers in Psychology, 8, 1-10. https://doi.org/10.3389/ fpsyg.2017.00895

Likert, R. (1932). A technique for the measurement of attitudes. Archives of Psychology, 22(140), 1-55.

Lin, H. S., Hong, Z. R., Wang, H. H., \& Lee, S. T. (2011). Using reflective peer assessment to promote students' conceptual understanding through asynchronous discussions. Journal of Educational Technology E Society, 14(3), 178-189.

Lincoln, Y. S., \& Guba, E. G. (1985). Naturalistic inquiry. SAGE. https:/ / doi.org/10.1016/0147-1767(85)9006 2-8

Lunetta, V. N., Hofstein, A. \& Clough, M. P. (2007) Learning and teaching in the school science laboratory: an analysis of research, theory, and practice. In S. K. Abell \& N. G. Lederman (Eds.), Handbook of research on science education (pp. 393441). Lawrence Erlbaum.

Malathi, S., \& Rohini, R. (2017). Problems faced by the physical science teachers in doing practical work in higher secondary schools at Aranthangi educational district. International Journal of Science and Research, 6(1), 133-135. https://doi.org/ 10.21275/ART20163993

Manz, E. (2020). Rethinking the classroom science investigation. Journal of Research in Science Teaching, 57(3), 1-46. https:/ / doi.org/10.1002/tea.21625

Marshall, J. C., Horton, R., Igo, B. L., \& Switzer, D. M. (2009). K-12 science and mathematics teachers' beliefs about and use of inquiry in the classroom. International Journal of Science and Mathematics Education, 7(3), 575-596. https://doi.org/10.1007/ s10763-007-9122-7

Maulidya, S. R., Hasanah, R. U., \& Retnowati, E. (2017). Can goal-free problems facilitating students' flexible thinking? AIP Conference Proceedings, 1868, 050001. https:/ / doi.org/10.1063/1.4995128
Mavhunga, F., Kibirige, I., Chigonga, B., \& Ramaboka, M. (2016). Smartphones in public secondary schools: Views of matric graduates. Perspectives in Education, 34(3), 72-85. https://doi.org/10.18820/ 2519593X/pie.v34i3.6

Mazur, E. (2009). Farewell, lecture? Science, 323, 50-51. https:// doi.org/10.1126/science.1168927

$\mathrm{Ng}$, W., \& Nguyen, V. T. (2006). Investigating the integration of everyday phenomena and practical work in physics teaching in Vietnamese high schools. International Education Journal, 7(1), 36-50.

Ngonyani, M. S. (2010). Teacher' facilitation of learning for learners with disabilities in inclusive classrooms in Tanzania: Teachers' use of iterative teaching methods in inclusive classrooms. Universitetet I Oslo, Norway. https:/ / www.duo.uio.no/bitstream/handle/1085 2/32250/MussaxShaffiixNGONYANIxxMasterxsx ThesisxxM.xPhil.xSNEx.pdf?sequence=1\&isAllow ed $=\mathrm{y}$

Onwu, G., \& Stoffel, N. (2005). Instructional functions in large, under-resourced science classes: Perspectives of South African teachers. Perspectives in Education, 23(3), 65-75.

Osborne, J. (2015). Practical work in science: Misunderstood and badly used? School Science Review, 96(357), 16-24.

Pang, C., Lau, J., Seah, C. P., Cheong, L., \& Low, A. (2018). Socially challenged collaborative learning of secondary school students in Singapore. Education Sciences, 8(1), 24-34. https://doi.org/10.3390/ educsci8010024

Pyatt, K., \& Sims, R. (2012). Virtual and physical experimentation inquiry-based science labs: Attitudes, performance and access. Journal of Science Education and Technology, 21(1), 133-147. https:/ / doi.org/10. 1007/s10956-011-9291-6

Ramnarain, U. (2011). Teachers' use of questioning in supporting learners doing science investigations. South African Journal of Education, 31, 91-101. https://doi.org/10.15700/saje.v31n1a410

Ramnarain, U. (2014). Teachers' perceptions of inquirybased learning in urban, suburban, township and rural high schools: The context-specificity of science curriculum implementation in South Africa. Teaching and Teacher Education, 38, 65-75. https:/ / doi.org/10.1016/j.tate.2013.11.003

Ramnarain, U. (2020). Exploring the autonomy of South African school science learners when doing investigative inquiries for a science fair. Eurasia Journal of Mathematics, Science and Technology Education, 16(12), 1-9. https://doi.org/10.29333/ ejmste $/ 9128$

Ramnarain, U., \& Hlatswayo, M. (2018) Teacher beliefs and attitudes about inquiry-based learning in a rural school district in South Africa. South African Journal of Education, 38(1), 1-10. https://doi.org/ $10.15700 /$ saje. v38n1a1431 
Ramnarain, U., \& Kibirige, I. (2010). Learning through investigations: The role and place of SI in school science. In U. Ramnarain (Ed.), Teaching scientific investigations, (pp. 1-23). MacMillan.

Ramnarain, U., \& Schuster, D. (2014). The pedagogical orientations of South African physical sciences teachers towards inquiry or direct instructional approaches. Research in Science Education, 44(4), 627650. https:/ / doi.org/10.1007/s11165-013-9395-5

Rolfe, G. (2006). Validity, trustworthiness rigour: Quality and the idea of qualitative research. Journal of Advanced Nursing, 53(3), 304-310. https://doi.org/10.1111/j. 1365-2648. 2006.03727.x

Sangoseni, O., Hellman, M., \& Hill, C. (2013). Development and validation of a questionnaire to assess the effect of online learning on behaviours, attitude and clinical practices of physical therapists in United States regarding evidence-based practice. Internet Journal of Allied and Health Sciences Practices, 11, 1-12. https://doi.org/10.46743/1540-580X/ 2013.1439

Schunk, D. H. (2004). Learning theories: An educational perspective. Pearson Prentice Hall.

Schwartz, R. S., Lederman, N. G., \& Crawford, B. A. (2004). Developing views of nature of science in an authentic context: An explicit approach to bridging the gap between nature of science and scientific inquiry. Science Education, 88(4), 610-645. https:/ / doi.org/10.1002/sce.10128

Sedumedi, T. D. T. (2017). Practical work activities as a method of assessing learning in chemistry teaching. Eurasia Journal of Mathematics, Science and Technology Education, 13(6), 1765-1784. https:/ / doi.org/10.12973/eurasia.2017.00697a

Sierra-Llorente, J. G., Romero Mora, B. S., \& Palmezano Córdoba, Y. A. (2018). Nivel de desempeño autopercibido por futuras educadoras de párvulos sobre el uso pedagógico de TIC [Self-perceived level of performance by future pre-schooler teachers regarding the use of ICT]. Panorama, 12(22), 32-41.

Singh, S. K., \& Singh, R. J. (2012). Pre-service teachers' reflections of South African science classrooms. South African Journal of Higher Education, 26(1), 168180. https:/ / doi.org/10.20853/26-1-157

Smith, T. M., Desimone, L. M., Zeidner, T. L., Dunn, A. C., Bhatt, M., \& Rumyantseva, N. L. (2007). Inquiryoriented instruction in science: Who teaches that way? Education Evaluation and Policy Analysis, 29(3), 169-199.

https: / / doi.org/10.3102/0162373707306025
Strauss, A., \& Corbin, J. (1990). Basics of qualitative research: Grounded theory procedures and techniques. SAGE.

Tal, T., Krajcik, J. S., \& Blumenfeld, P. (2006). Urban schools teachers enacting. Journal of Research in Science Teaching, 43(7), 722-745. https://doi.org/ 10.1002/ tea.20102

Tilling, S. (2018). Ecological science fieldwork and secondary school biology in England: does a more secure future lie in geography? Curriculum Journal, 29(4), 538-556. https://doi.org/10.1080/09585176. 2018.1504315

Tsakeni, M. (2018). Inquiry-based practical work in physical sciences: Equitable access and social justice issues. Issues in Educational Research, 28(1), 187-201.

Umalusi, (2009). Report on the quality senior certificate assessment and examination. Council for Quality Assurance in General and Further Education and Training. RSA. http:/ / www.umalusi.org.za/docs /research/2009/ieb.pdf

Umalusi, (2018). Report on the quality assurance of the South African Comprehensive Assessment Institute (SACAI), November 2018 National Senior Certificate (NSC) examinations and assessment. https:/ / www.umalusi.org.za/docs/reports/2019 /SACAI\%20QAA \%20Report\%202018_010419.pdf

Vrieling, E., van den Beemt, A., \& De Laat, M. (2018). Facilitating social learning in teacher education: a case study. Studies in Continuing Education, 41(1), 76-93.

https:/ / doi.org/10.1080/0158037X.2018.1466779

Vygotsky, L. S. (1978). Mind in society: The development of higher psychological processes. Cambridge: Harvard University Press.

Williams, M. (2020). Fifth graders' use of gesture and models when translanguaging during a content and language integrated science class in Hong Kong. International Journal of Bilingual Education and Bilingualism, 1-20. https://doi.org/10.1080/ 13670050.2020.1754752

Williams, M. E. (2017). An examination of technology training experiences from teacher candidacy to inservice professional development. Journal of Instructional Pedagogies, 19, 1-20.

Yeboah, R., Asante, E. A., \& Opoku-Asare, N. A. (2016). Teaching interactive art lessons with recycled waste materials as instructional resources. Journal of Education and Practice, 7(14), 38-59. 


\section{APPENDIX A}

\section{Qualitative-Classroom observations of learner activities during SI lessons}

\begin{tabular}{|c|c|c|c|}
\hline Item & Observable SI practices & $\begin{array}{c}\text { Not done } \\
\text { (non-compliance) } \\
\text { frequency no. \& }(\%)\end{array}$ & $\begin{array}{l}\text { Done (compliance) } \\
\text { frequency no. \& (\%) }\end{array}$ \\
\hline LO01 & Leading learners to formulate SI hypotheses & $28(70)$ & $12(30)$ \\
\hline LO02 & Posing questions to stimulate learner curiosity & $30(75)$ & $10(25)$ \\
\hline LO03 & Granting learners autonomy to construct their explanations & $32(80)$ & $8(20)$ \\
\hline LO04 & Learners doing learner-centred activities and communicating during SI & $32(80)$ & $8(20)$ \\
\hline LO05 & Creating opportunities for learners to use multiple methods in & $32(80)$ & $8(20)$ \\
\hline $\begin{array}{l}\stackrel{N}{\check{L}} \\
\tilde{0}\end{array}$ & $\begin{array}{l}\text { investigations questions like analyzing and interpreting data, arguing } \\
\text { from evidence, and evaluating findings }\end{array}$ & & \\
\hline POت & $\begin{array}{l}\text { Educator conducts the scientific investigation whilst learners watch the } \\
\text { demonstration }\end{array}$ & $12(30)$ & $28(70)$ \\
\hline $\mathrm{O}_{\mathrm{LO} 07}$ & Affording learners opportunities to plan SI on their own. & 40 (100) & $0(0)$ \\
\hline LO08 & Educator teaching SI theoretically, explained and learners were passive & $32(80)$ & $8(20)$ \\
\hline LO09 & Educator improvises during lack of science equipment & $38(95)$ & $2(5)$ \\
\hline LO10 & Learners watch videotaped SI & $36(90)$ & $4(10)$ \\
\hline LO11 & Constructing and administering self-initiated worksheet & $32(80)$ & $8(20)$ \\
\hline LO12 & Engaging learners in open-ended SI tasks & $40(100)$ & $0(0)$ \\
\hline
\end{tabular}




\section{APPENDIX B}

Qualitative-Teachers' perceptions of practical work, inquiry, and SI from interviews

\begin{tabular}{|c|c|c|c|c|}
\hline & Sample of verbatim quotations & Code & Sub-theme & Theme-1 \\
\hline & Practical work & Practical work & & \\
\hline & "aids to do experiments and follow given steps." (Teacher 1 ) & aids to do experiments & Different & Different \\
\hline & "Practical work is when you involve yourself in the & is hands-on activity & & \\
\hline & handling of apparatus." (Teacher 7) & is namus-on activity & & \\
\hline & $\begin{array}{l}\text { "Learners perform practical work which includes } \\
\text { investigations to prove theory. It is hands-on. It involves } \\
\text { handling of apparatus." (Teacher } 5 \text { ) }\end{array}$ & $\begin{array}{l}\text { is investigations to } \\
\text { prove theory }\end{array}$ & $\begin{array}{l}\text { Practical work is } \\
\text { hands-on or } \\
\text { activity based }\end{array}$ & $\begin{array}{l}\text { work, } \\
\text { inquiry, } \\
\text { and SI }\end{array}$ \\
\hline & $\begin{array}{l}\text { "In practical work learners present whatever they have. } \\
\text { Even if they do not do practical with apparatus in the } \\
\text { laboratory. Answering questions from the Work sheets is also } \\
\text { practical work." (Teacher 3) }\end{array}$ & $\begin{array}{l}\text { is similar to answering } \\
\text { questions from the } \\
\text { worksheets }\end{array}$ & $\begin{array}{l}\text { Searching } \\
\text { information }\end{array}$ & \\
\hline & "Learners do practical work and produce results." (Teacher 8) & includes inquiry & Teach and assess & \\
\hline & $\begin{array}{l}\text { "Practical work is done physically in order to find whether } \\
\text { or not the findings of the research are supported by the } \\
\text { findings of your own practical work." (Teacher 9) }\end{array}$ & & & \\
\hline & Inquiry & & & \\
\hline 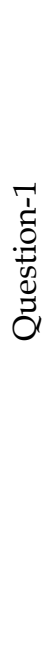 & $\begin{array}{l}\text { "When we talk about inquiry it might not be practical per se, } \\
\text { it is about following instructions to gather information." } \\
\text { (Teacher 1) } \\
\text { "Inquiry is mental searching of facts about the topic." } \\
\text { (Teacher 6) } \\
\text { "In inquiry learners may not even use their hands. I assess } \\
\text { what they have in their minds from searching. } \\
\text { With inquiry you are looking at a topic, you go around and } \\
\text { ask people about the topic and get the perfect answer to solve } \\
\text { whatever." (Teacher 7) } \\
\text { "With inquiry you must conduct a research and find more } \\
\text { details about the phenomenon." (Teacher 9) } \\
\text { "Inquiry is about studying the phenomenon deeper." } \\
\text { (Teacher 10) }\end{array}$ & $\begin{array}{l}\text { Follow instructions } \\
\text { No manipulation of } \\
\text { objects } \\
\text { Assess theory } \\
\text { knowledge } \\
\text { Searching for } \\
\text { information }\end{array}$ & $\begin{array}{l}\text { No commitment } \\
\text { to hands-on } \\
\text { teaching }\end{array}$ & \\
\hline & Investigations & & & \\
\hline & $\begin{array}{l}\text { "When learners manipulate objects, they are doing SI. No } \\
\text { hands-on tasks learners follow what is designed. They follow } \\
\text { strict prescribed methods, which are practical work, } \\
\text { experimentation, investigation and inquiry, and hands-on } \\
\text { may be used as the teacher saw fit as investigations without } \\
\text { practical work and inquiry done." (Teacher 4) } \\
\text { "Learners may get assistance from whoever, for example } \\
\text { parents. That is SI take long period." (Teacher 3) } \\
\text { "You combine inquiry and practical work to make up SI. Let's } \\
\text { say this investigation can be done in different ways. Learners } \\
\text { can come with their own methods to get the findings." } \\
\text { (Teacher 9) }\end{array}$ & $\begin{array}{l}\text { Hands-on activities are } \\
\text { optional } \\
\text { Theory content } \\
\text { teaching } \\
\text { SI is amalgamation of } \\
\text { practical work and } \\
\text { inquiry }\end{array}$ & Confusing terms & \\
\hline
\end{tabular}




\section{APPENDIX C}

\section{Themes 2 and 3-Teachers' challenges regarding facilitating SI}

\begin{tabular}{|c|c|c|c|c|}
\hline & Sample of verbatim quotations & Code & Sub-theme & Theme-2 \\
\hline \multirow[t]{2}{*}{ } & $\begin{array}{l}\text { "Lack of advanced skills. I am not equipped with the skills } \\
\text { of doing SI. I need skills and knowledge to involve learners } \\
\text { in SI." (Teacher 4) } \\
\text { "I am not equipped with the skill of practically assessing. } \\
\text { Normally I take the one that is provided by the Department } \\
\text { Education in the pacesetters. This is because I enjoy teaching } \\
\text { more than doing SI." (Teacher 2) } \\
\text { "I cannot say I was empowered to improvise. I did not get } \\
\text { proper guidance to do SI." (Teacher 10) }\end{array}$ & $\begin{array}{l}\text { Lack of SI teaching skil } \\
\text { Lack of SI skills }\end{array}$ & $\begin{array}{l}\text { llLack of skills and } \\
\text { resource } \\
\text { Educators } \\
\text { challenges in } \\
\text { assessing SI }\end{array}$ & $\begin{array}{l}\text { Teachers' } \\
\text { lack of skills } \\
\text { to facilitate } \\
\text { SI }\end{array}$ \\
\hline & & Code & Sub-theme & Theme-3 \\
\hline 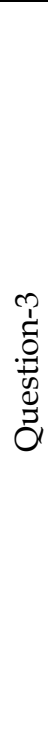 & $\begin{array}{l}\text { "Lack of resources, being under-skilled and lack of space. } \\
\text { Sometimes we just emulate the investigation, not really } \\
\text { doing it." (Educator 5) } \\
\text { "There are not enough facilities. I am not equipped with the } \\
\text { skill of practically assessing learners' level of science process } \\
\text { skills acquisition during SI. That is why I usually follow } \\
\text { programmed SI." (Educator 6) } \\
\text { "Our laboratory is used as a store room for science } \\
\text { materials. There is a problem of lack of space. Sometimes I } \\
\text { am forced to do scientific investigation in classroom setting } \\
\text { instead of laboratory. So learners cannot do investigations } \\
\text { practically. What if learners get hurt or break apparatus. } \\
\text { That is why I demonstrate." (Educator } 8 \text { ) } \\
\text { "Sometimes we group learners to share the few apparatus } \\
\text { that we have. This makes SI costly in terms of } \\
\text { time/duration. Big classes. Apparatus is very expensive too. } \\
\text { We do not know what to do to teach investigations in these } \\
\text { conditions." (Teacher 9) }\end{array}$ & $\begin{array}{l}\text { Laboratory used for } \\
\text { storage } \\
\text { Inability to improvise }\end{array}$ & $\begin{array}{l}\text { Limitation of } \\
\text { resources } \\
\text { Inadequate } \\
\text { infrastructure } \\
\text { Inability to use } \\
\text { the resources }\end{array}$ & $\begin{array}{l}\text { Inadequate } \\
\text { resources to } \\
\text { facilitate SI }\end{array}$ \\
\hline
\end{tabular}


APPENDIX D-CODEBOOK SAMPLE

Title: Teachers' Perceptions of Facilitating Scientific Investigations (SI)

\section{Perceptions}

Type of perceptions observed

Reading and Re-reading transcripts practical work, inquiry and investigation. Keeping track of key words frequency and noting patterns.

Facilitating Skills

SI facilitation skills

Do teachers possess the skills to facilitate SI? Noting comments on their skills or a lack thereof.

\section{Challenges}

\section{Challenges in facilitating SI}

Teachers' main challenge in facilitating SI. Tracking frequency of the challenges that hindered teachers from facilitating SI.

\section{http://www.ejmste.com}

